\title{
Magik on the Mounds: The (Re) Enchanted Spaces of the House on the Rock
}

\author{
Tess Pierce ${ }^{1 *}$ and Derek Sweet ${ }^{2}$
}

${ }^{1}$ Faculty of Criminology, Justice, and Policy Studies, Communication Program University of Ontario Institute of Technology Oshawa, ON, Canada ${ }^{2}$ Communication Studies Luther College, USA

\begin{abstract}
To explore the intersection of magic, imagination, and place as a buttress against continued disenchantment furthered by an over reliance on rational thought, we turn to the (re)enchanted rhetoric of Starhawk, an eco-feminist peace activist and witch, to analyze the House on the Rock. We focused on the ways in which some rhetorical spaces challenge the postmodern idea of the disenchanting overemphasis on moral perfection, logic, and technological rationalization. Intertwined with cultural and political institutions, disenchanted rhetoric ensnares individuals in stultified existence that eliminates diversity, reifies hierarchy, dismisses creativity, and limits individuality. In positioning the House on the Rock as a rhetorical text we suggest that liminal spaces liberate individuals from the fetters of societal expectations, hierarchies, and institutions, offer a safe vantage point by which to examine conflicting viewpoints, and ultimately blur the distinction between entrenched understandings and new ways of knowing and seeing.
\end{abstract}

Keywords: Rhetoric of place; Starhawk; Disenchantment; (Re) Enchantment

\section{Introduction}

On December 25, 2012, NPR's All Things Considered broadcast a story how E.T.A. Hoffman's short story, "Nutcracker and Mouse King”. Transformed into Tchaikovsky's much beloved holiday ballet. Indicative of what would become recognized as 19th century German Romanticism; Hoffman's tale of animate toys, voracious mice, and fantasy worlds exhibits a much darker, almost Gothic, tone when compared to the modern Christmas classic. The original story is one of interspecies warfare as an army of mice, led by the fearsome, seven headed Mouse King, battle the Nutcracker and other living dolls for control of the Stahlbaum household. Marie, Hoffman's protagonist, is stalked, terrorized, and even injured during her encounters with the unrelenting mice. As in the ballet, the Nutcracker and his animated cohort dispose of the fearsome Mouse King and Maria eventually experiences the wonders of the Doll Kingdom. Unlike the ballet, however, Hoffman's ending suggests Maria's experiences were not simply a result of fever dreams or the overactive imagination of a sleepy child. As the final line of Hoffman's tale reveals, Maria "it is said, is at this hour queen of a land, ... where the most beautiful, the most wonderful things can be seen by those who will only have eyes for them" [1]. Despite the difference in tone, the two versions of the tale share a thematic exploration of the intersection of magic, imagination, and place. In the traditional ballet, magic and imagination is banished to the realm of Clara's dreams, while the original story, explores the possibility of fantasy made manifest in the most mundane of places: a home. The closing sentence of the story situates Orange Brook, Christmas Woods, and the Puppet Kingdom as actual, physical places rather than a child's fantasy kingdom. At the heart of Hoffman's magical, albeit macabre, tale is the epistemological clash between the restrained rationality of the Enlightenment and the playful imagination of Romanticism. Hoffman's inclusion of the reserved and unimaginative Stahlbaum household juxtaposed with enchanted worlds exemplifies the literary use of place to critique the restrictive rationality of a "world which is stifling or falling apart" [2]. Nearly two hundred years later, the tensions between a worldview grounded in the pursuit of incontrovertible explanations and causes, as opposed to one grounded in imagination and mystery persist. Like Hoffman, our project explores the idea that contemporary narratives still possess the rhetorical power to enchant physical spaces.

To explore the intersections of magic, imagination and built space we turn to the (re)enchanted rhetoric of Starhawk. Starhawk's overall discourse suggests a world devoid of magic, mystery, and imagination, a disenchanted world dominated by analytical thought, instrumental action, and mechanistic relations, is world in which "something, someone, is missing" [3]. One means of counteracting or resisting the pervasive influence of disenchantment is through the creation of sacred space. Creating sacred space, according to Star hawk, is the embodied rhetorical practice of transforming any location, a sitting room, a sidewalk, or a roadside attraction, into a place of deep individual and cultural reflection and reawakening. Such rhetorically (re)enchanted spaces offer individuals the opportunity to step back from the pervasive social pressures of disenchanted existence and contemplate the liberatory potential of the intuitive, the avant-garde, and the ineffable. Grounded in Starhawk's conception of sacred space, we argue that the rhetorical enchantment of spaces constitutes a deliberate attempt to counterbalance a cultural fixation on disenchanted ways of thinking, knowing, and being. Our argument proceeds in the following manner. We begin our exploration of rhetorically constructed spaces of (re) enchantment by unpacking the notion of the disenchanted world. We then offer the possibility of (re)enchanted space as a rhetorical response to cultural disenchantment through our case study of the House on the Rock attraction to illustrate the themes of displacement and the sublime and the emancipatory potential of rhetorically constructed space. Our

*Corresponding author: Tess Pierce, Assistant Professor, Faculty of Criminology, Justice and Policy Studies, Communication Program, University of Ontario Institute of Technology Oshawa, ON, Canada, Tel: 1-905-721-8668/3820 E-mail: teresa.pierce@uoit.ca

Received September 19, 2013; Accepted December 17, 2013; Published January 14, 2014

Citation: Pierce T, Sweet D (2014) Magik on the Mounds: The $(\operatorname{Re})$ Enchanted Spaces of the House on the Rock. Arts Social Sci J 5: 062. doi: 10.4172/2151 6200.1000062

Copyright: (C) 2014 Pierce T, et al. This is an open-access article distributed under the terms of the Creative Commons Attribution License, which permits unrestricted use, distribution, and reproduction in any medium, provided the original author and source are credited. 
concluding discussion addresses the implications for rhetorical theory and the transformative possibilities of embodied (re) enchantment.

\section{Towards a Rhetoric of (Re) Enchanted Spaces \\ From disenchantment to embodied (Re) enchantment}

Weber et al. [4] conceptualization of disenchantment is the foundation for this project [4]. According to Gerth et al. [5], Weber claimed disenchantment is a progressive process that includes both moral perfection and technological rationalization. Weber's conceptualization of disenchantment is not without critics. For some in Western sciences, for example, disenchantment is seen as the decline of physical mystery. We may use the metaphor of Mother Nature to help children understand complex environmental issues, but we do not literally believe a real person is controlling the world. Jenkins [6] acknowledged that Weber understood the contradictory nature of modernity but he also underestimated the power of subversion. For, Weber et al. and Jenkins [4,6] distinction between formality and informality is a conceptual distinction, not a practical application. Even in the most formal or rational aspects of today's life, irrational and magical experiences abound. In a disenchanted world, a doubleedged process occurs and everything becomes possible while, at the same time, the more we know and understand; the more we do not know. We concur with Jenkins. The world today may actually be more mysterious, and the rational pursuit of knowledge is no longer enough. Disenchantment is a stimulus for enchantment, but enchantment may also stimulate disenchantment. It is this contradiction that this project addresses.

We describe enchantment using Landy and Saler's [7] conceptualization of par excellence, "the modern enchantment which simultaneously enchants and disenchants, which delights but does not delude". This differs from a binary approach that dominates disenchantment discourse, privileges rational thought, and includes the notion that, if we choose enchantment, we must reject Western thought. We concur with Bennett's alternative viewpoint that a rational world discourages enchantment. Bennett [8] wrote, "To be enchanted, then, is to participate in a momentarily immobilizing encounter; it is to be transfixed, spellbound". For Bennett, the mood of the experience includes a state of surprise that returns you to a childlike excitement of life. The possibility for enchantment is for everyone. Bennett referred to this possibility as the "wonder of the minor experience". Enchantment may not always be a positive experience (as anyone who falls in love with the wrong person may realize) but it is necessary for a full life. Enchanted spaces, like those of The House on the Rock, help us to celebrate imagination, bringing richness to our lives. There are many ways of understanding (re) enchantment, from the secular to the religious because (re) enchantment requires mystery, wonder, purpose, and order. Like, Landy and Saler and Bennett $[7,8]$ suggested the mundane is important, but unlike Bennett, they saw the need for the belief in miracles that challenge or alter the accepted order of things. They claimed that these miracles, or secular epiphanies, are those brief moments when we discover something "quasi-mystical" about a world larger than ourselves. "Ahamoments" are sudden and dramatic events when we experience clarity in a way that surprises us. Secular epiphanies unlock previously unknown or intentionally hidden desires, wants, or needs. The revelation comes from within the person and this may drastically alter her view of the world. A secular epiphany requires active participation in the process even if the trigger to the experience is unknown. This experience leaves the person with the feeling she can transform her world. Leopold [9] wrote of his epiphany that transformed his life-path from forest ranger to environmentalist:
We reached the old wolf in time to watch a fierce green fire dying in her eyes. I realized then, and have known ever since, that there was something new to me in those eyes-something known only to her and to the mountain. I was young then, and full of trigger-itch; I thought that because fewer wolves meant more deer, that no wolves would mean hunters' paradise. But after seeing the green fire die, I sensed that neither the wolf nor the mountain agreed with such a view.

In contrast, a religious epiphany is where a person is "touched" by a divine hand. In this passive experience, a person has no choice but to transform. The conversion of St. Paul on the road to Damascus is an example of a religious epiphany. On his ride, he was struck down and thrown from his horse by a light brighter than the sun. The voice of God commanded him to stop his reign of terror against the Christians. In an instant, Saul transformed into Paul.

These magical experiences are what Jenkins referred to when he wrote, "Disenchantment has indeed been the fate of the world, but this has only served to open up new vistas of possible (re) enchantment" [6]. People seem bound and determined to infuse their lives with magic, gods/goddesses, and awe-inspiring spectacles and films. The problem with cinematic experiences like the Avengers and Harry Potter, for example, is that the illusion shatters the moment the film ends. Despite the spectacle of sound and image, viewers are never truly part of the enchantment but remain forever disengaged. But we can have enchanting experiences that stay with us and intensify over time. Often these are connected to specific places like the House on the Rock. These spaces manipulate us in some way and we, in turn, manipulate them which results in a transformation or embodied (re) enchantment.

\section{The rhetoric of place}

Since the mid-1980s, rhetorical scholars explored the notion of physical spaces, memorials, main streets, and museums as symbolic communication capable of inducing nostalgic reflection, reverent remembrance, cultural deference, and political consideration [10-15]. In her analysis of the Vietnam Veterans Memorial, Foss claimed the monument functions as a standard for future memorials because of the ways it appeals to all visitors, whether personally touched by the Vietnam War. Foss [10] described how the installation breaks conventional war memorial design and "does not distance or threaten the visitor, instead, it invites, draws us in and almost seems to embrace us". Similarly, Blair et al. [11] Wrote of the memorial's power, and magical qualities. They argued that "built environments" conjure particular meanings and understandings into existence (and dispel others) thereby permeating human experience with almost imperceptible, yet completely ubiquitous, attempts to illuminate/obscure cultural values, direct/ restrict bodily motility, encourage/discourage consumption, and exalt/ denounce particular ways of knowing, being, and living. In short, the carefully considered design of everything from a storefront to public memorial displays "rhetoricalness" in that these places encourage individuals to view themselves, others, and the world around them in particular ways.

Given that human agents are immersed in the symbolic trappings of constituted space, one might argue intentionally designed places shape lives, both individual and communal, in a way similar to culture. Indeed, George [16] suggested "place may be understood as a producer of meaning which situates culture, and thus, both contributes to and mediates the practices of everyday life". He wrote of how the rhetoric of intentionally constituted places is a symbolic enterprise and an embodied material practice. In other words, physical spaces affect the body directly. We do not claim that this is unique to intentionally 
designed spaces. But we do claim that moving through any number of physical spaces, a person brings her own perceptions, interpretations, and understandings to all symbolic encounters. Just as important as her own subjective experience, however, is the collaborative meaning making encouraged by the intentional deployment of particular structures, designs, and visual aesthetics. Together, subjective experience and the guided, immersive rhetoric of constructed spaces constitute a dynamic moment of embodied meaning making capable of transforming everything from cultural understandings to individual subjectivities. For example, Cameron [17] described museums as "structured samples of reality" that offer "new and challenging perceptions of reality" to be "seen and heard by all" who enter these uniquely ritualized spaces. Bringing forth these "new and challenging perceptions of reality", particularly in relation to ritualized space, is the bailiwick of Starhawkian rhetoric.

\section{Revealing the Enchantment: Starhawkian Rhetoric}

Foss and Griffin [18] unpacked the rhetorical theory of Starhawk's spirituality-based approach to social change and civil disobedience. In a review of Starhawk's work, Foss and Griffin noted it was grounded in the principles of Wiccan spiritual practice, immanence, interconnection, and community. The transformational potential of Starhawk rhetoric is premised in the idea of a disenchanted world ordered around the power-over of dominance, oppression, and control. Starhawk [19] suggested a culture rooted in dominance and control promotes a perpetual cycle of comparisons and competitions, fills individuals with fear, distrust, and self-hate, and encourages the marginalization of those who think, act, or believe differently than the hegemonic majority. Starhawk referred to the disenchanted way of life as "estrangement" because its essence is that we do not see ourselves as part of the world. We are strangers to nature, to other human beings, to parts of ourselves. We see the world as made up of separate, isolated, nonliving parts that have no inherent value. Among things inherently separate and lifeless, the only power relationships possible are those of manipulation and domination [20].

Inundated by disenchanting discourses, individuals interpret and experience one another, and the broader culture, as static, inflexible, atomistic, and mechanistic. Intertwined with the cultural and political institutions of which it is a part, a rhetoric of domination ensnares individuals in a stultified existence that eliminates diversity, reifies hierarchy, dismisses creativity, limits individuality and contributes to any number of cultural ills: "sexism, racism, poverty, social injustice, war, or environmental degradation" [3]. Despite her rather bleak assessment, the vast majority of Starhawk's work focuses on ways to (re)enchant a disenchanted world. She challenges individuals to "break spells, to shatter the ensorcellment that keeps us psychologically locked away from the natural world", and actively pursue "healing, expanded awareness, and intensified life" [21]. As Foss and Griffin [18] pointed out, Starhawk's rhetorical call to (re) enchant everyday life begins with the fundamental assumption that all things, people, animals, plants, and even stones, possess inherent value. Rather than viewing all parts of the world as separate and disconnected, inherent value suggests everything, even people and things which bother or baffle us, play an important role. Therefore, a worldview based on immanent value and inter connection suggests when one part of the system is out of balance, it impacts the entire system. The suffering of one is the suffering of all. Recognizing the deep interconnection of the planet-wide ecosystem, from interactions within community to broader interactions with the natural world, requires individuals to revisit their place in the world.

This new way of seeing the world, argued Starhawk [19] calls on people to embody acts of "resistance and renewal", to acknowledge the incomprehensible complexity of life, and to live "in ways that make possible encounter with mystery". Mystery, described as the paradoxical difference between the ordinary and extraordinary, the known and unknown, or, in the case of our current work, the disenchanted and the enchanted, enables communicators to establish common ground through the simultaneous inscrutability and know ability of human experience. A world dominated by the disenchanting discourses of logic and rationality, moral perfection, and stifling social institutions denies an important element of the human condition and, as a result, contributes to any number of communal ills. It is important to note Starhawk does not denounce rationality, the scientific method, or a particular culture belief system as inherently problematic. Rather, she argued that an overreliance on ideas like these, to the exclusion of all others, leads to a harmful societal imbalance. Starhawk [21] advocated for a cultural reawakening, or ( $\mathrm{re}$ ) enchantment that balances modernist preoccupations of critical rational discernment with the complex mysteries experienced in the everyday affairs of human lives. Nowhere is this clearer than in her musings on the conflict between science and the sacred. "When our sense of the sacred is based not upon dogma but upon observation and wonder at what is, no contradiction exists between theories of science and those of faith". When science and spirit are reconciled, the world becomes re-enchanted, full of wonder and magic. In other words, we have become a society where information may be at our fingertips, and enchantment seems out of our reach, but we still grasp at a chance to be mystified. While the existing conceptualizations of Starhawkian rhetoric position magic as central to the practice of contemporary witchcraft, magic's role in rhetorical endeavours is decidedly underdeveloped. Our reading of Starhawk suggests a much greater importance for the role of magic: rhetoric is, in fact, a literal form of magic. The magic of the (modern) Wiccan tradition does not turn people into toads, grant the power of flight to a broomstick, enable immortality, or endow a person with superhuman abilities [19-22]. Instead, practical magic "has to do with forms, with structures, with images that can shift us out of the limitations imposed by our culture with visions that hint at possibilities of fulfillment not offered by the empty world" [20]. Throughout the corpus of her work, Starhawk made one argument abundantly clear: magic is the means by which humans might heal an ailing world, right social wrongs, and challenge institutionalized systems of power. The manifestation of magic is not accomplished through mixing eye of newt with mandrake root, but through focusing the will. Magic permeates and penetrates a political speech, a love sonnet, a kind word to a stranger, and a queer pride parade. Through communication, a form of magic, a rhetor may reinforce traditional beliefs, challenge cultural values, or encourage new communal understandings. As Starhawk intimated, "the use of language to shape consciousness is an important branch of magic" [19]. Covino [23] explained magic and rhetoric can be identified both with a play of ambiguities, or with the absolute determination of meaning by decree. As arresting forces, magic and rhetoric, enable purveyors of the respective arts to bring a degree of fixity, constraint, or constancy to meanings, subjectivities and cultural norms. Conversely, generative magic and rhetoric, grounded in multiple ways of knowing, seeing, and being in the world, can challenge cultural fixity. While we do not equate (re) enchantment with a literal sense of magic, we do echo Starhawk and assert that physical spaces can, and do, offer the potential for significant physical and psychological transformation, capable of challenging the predominant cultural obsession with a disenchanted existence. Throughout her writings Starhawk [22] emphasized the importance of liminal places where individuals come together "on the boundaries of ordinary space and time and explore "alternate realities" where "the 
past and present are open to us". Such spaces liberate individuals from the fetters of societal expectations, hierarchies, and institutions, offer a safe vantage point by which to examine conflicting viewpoints, and ultimately blur the distinction between entrenched understandings and new ways of knowing and seeing. Sacred spaces allow people to reflect, reawaken to the awe-filled magic of the universe, and resist the prospect of living a disenchanted life. As Starhawk [19] made clear, sacred spaces allow people to "change consciousness. Travel in the imagination". She pointed out that humans have created such spaces throughout history by erecting pyramids, stone circles, and mound effigies as markers for sites of reverence and spiritual power. Contemporary humans continue to "build churches, cathedrals, and temples to mark sacred space architecturally. Of particular note is Starhawk's assertion regarding the potential sacredness of nearly any space. Establishing sacred space requires the embodied participation of an individual or individuals. In other words, sacred space is called into being by the language and bodily actions of individuals. Whether one is meditating in a Zen monastery or wandering the exhibits of The House on the Rock, a space takes on a sacred/enchanted appearance as a result of the embodied interactions of those inhabiting the respective spaces. In Starhawk's Wiccan theology, sacred space is enacted by several ritualized steps: drawing the circle, invoking, working magic, going places, feasting, and transition of return [19]. Four of these ideas-drawing the circle, invoking, working magic, going/returning-relate to our idea of (re) enchanted space. To illustrate these four ideas, we turn our attention to the House on the Rock. The House on the Rock (HOTR) is located west of Madison in the Driftless Region ${ }^{1}$ of southwest Wisconsin. In the 1940s Alex Jordan began building a weekend retreat on Shelter Rock. Word of his house spread and, although Jordan never intended it to become a tourist attraction, visitors flocked to see this unique structure. The house enchants and mystifies over 400,000 visitors from all over the world each year and is a place filled with "visionary architecture, eclectic collections, and incredible stories..." [24]. It took us five hours to walk through all the buildings and gardens. While the entire site is worthy of analysis, we concentrated on two popular sections: the Streets of Yesterday, and the Carousel.

\section{Drawing the circle}

Starhawk [22] described drawing the circle as actions that delineate a kind of boundary or barrier between worlds "that limits and contains the movements of subtle forces" and call for a shift in consciousness or perception. Such delineation might be subtle and permeable, like a ring of people gathering in a park, or more explicit and fixed, like a series of statues lining a path to a local attraction. Regardless, rhetorical efforts to draw a circle prepare individuals for a transition from one way of thinking to another and caution a possible change in perception looms ahead. As Dickinson et al. [15] pointed out in their discussion of the western expanses surrounding the Plains Indian Museum, the geography surrounding a specific rhetorical space may play an important role in orienting audiences to particular symbolic experiences. This physical, embodied journey through specific landscapes prepares audiences members for an experiential transformation. The drawing of the circle starts before you get to the attraction and is facilitated by the natural boundaries and landscape surrounding the House on the Rock. They are resonates with topography deeply connected with the notion of America's heartland. Interstate and state highways snake over and between rolling hills dotted with forests, farmland, and the occasional limestone outcropping that characterizes Karst topography.

'The term "Driftless Region" refers to a geographical area untouched by glaciers For more information on this area in Wisconsin go to: http://driftlesswisconsin.com
A simple wooden sign reading "House on the Rock" points down an unremarkable driveway that serves as the entrance to the attraction. Beside the sign, however, is an indication of the transformed realities awaiting visitors: a 12 -foot sculpture that looks like a cross between a terra cotta strawberry pot, a genie's lamp, and a burial urn. A number of mythical creatures winged salamanders, dragons, and lizards, crawl across the surface of the urn.

A canopy of trees covers the half-mile lane running from the state highway to the parking lot creating an arboreal tunnel. Several of the fantastic urn sculptures appear sporadically on the side of the road never letting those navigating the driveway forget this is no ordinary forest lane. At the end of the driveway, patrons make their way to

the Visitors Center where they encounter a wooden sign reading "Where imagination comes to life", near a wood carved wizard, complete with flowing robes, staff, and wand, who points toward the main entrance. Visitors aretransitioned into the experience guided by Alex Jordan's vision of place. The parking lot is another line of demarcation between what is real and now, and what is unknown and yet to come. And, as Starhawk [22] wrote, ultimately, the space between disenchanted and (re)enchanted space invites a person to "suspend disbelief" and allow herself or himself to "respond... emotionally" to "actions, symbols, tangibles". In casting the circle, the visitor actively participates in changing the energy from mundane to extraordinary even before getting out of the vehicle.

\section{Invoking}

Invoking is the purposeful deployment of symbols within a (re) enchanted space. Throughout her work, Starhawk [22] acknowledges the efficacy of discursive and non-discursive symbols as ways of seeing and evaluating the "relationships and actions of a culture. They are associated with colors, animals, places, plants, qualities, stories and all of which further describe the pattern". Naming and defining that which is granted or should have, cultural value gives rise to specific patterns of meaning that bring a sense of order and understanding to everyday life. In discussing symbols, power and human perceptions, Starhawk [19] alluded to the meaning-making potential of created rhetorical spaces. She wrote: These patterns are never accidental; they are the concrete manifestations of a culture's deepest assumptions, structures, and power relationships. A Gothic cathedral, with its stone walls, lofty spires reaching skyward, and long, narrow spaces in which a huge congregation focuses all their attention on the priest at the altar, embodies a concept of God, and of power, quite different from a Sweat Lodge built on bent branches and skins on bare earth, in which a small group sits in a circle together. These patterns are evident in Jordan's designs and begin in the way him controls the path visitors take through the space. While this is not unique to most attractions, it is unique in the ways the path invokes meaning or contradicts the meanings we had expected. A series of contradictions emerge from the manipulation. For example, guests follow the ramps from the Visitor's Center through water features that resemble a zen garden. This forms an informal community of like-minded patrons who trace the steps of previous visitors. Connections are made reading comments in the guest books or looking at the photos and images on the wall. But once inside the Gate House, this camaraderie diverges and each person interprets the symbols in ways shaped by personal experiences to create alternative narratives. In other words, invoking the circle plants a seed of empowerment nourished by those who came before us and grows as a result of this interconnection. For Starhawk [19], invoking is where the potential for transformation begins. Invoking is an empowered action "that does not accept the terms of the system". The twists and 
turns of the pathway from garden to Gate House become part of our personal experiential repertoire that then influences the way we make sense of our world.

The streets of yesterday: In his analysis of iconic Route 66, Wood [25] claimed "meaningful touristic pleasure comes from recognizing its inauthenticity" Like Route 66, the House on the Rock plays on the American myth of nostalgia and the tourists' fantasies surrounding this myth and is true simulacra; a place that refers to other places, filled with artifacts that reference other artifacts which may or may not be "authentic". The Streets of Yesterday (SoY) is filled with examples of American culture. To paraphrase Wood, one does not visit the House on the Rock to see the Streets of Yesterday. One visits the Streets of Yesterday to see what we fantasized yesterday to be. The fantasy is not about the actual place; it is about visitors 'mediated memories and experiencing the nostalgia of a simpler way of life. For us, this mediated fantasy started with sound. We were no longer walking quietly on soft carpeting but clopping on brick streets. A barber shop quartet harmonized from an unseen gazebo. An ethereal pump organ played what seemed like a variation of "Pennies from Heaven" a tune popular in 1930s. The SoY transcended reality. We felt transported to an era that "never really was" and time became ambiguous. Both of us were equally enchanted. It should be noted that, we are in the same general stage in our academic careers; we are a full generation apart in age with one set of grandparents from the late 1800s and the other from the depressionera. Even with this disparity we each felt a nostalgic connection. In addition to the sounds, our visual experiences challenged our ideas of authentic life at the turn-of-the-century. For instance, the apothecary shop displayed both an electric belt (circa 1920) guaranteed to improve the male physique, and a "baby in the bottle" (circa 1850s), an elixir promising a fertile womb. The Soy exhibits authentic period pieces but with the "Jordan touch". The trees lining the lanes are "Portland Oaks" made from sculpted cement. The "Glass Shoppe" looks more like a modern collection of antiques than a storefront from the turn of the century. Hidden in plain sight is a brass statute of Alex Jordan keeping watchful eyes on us all. And tucked around the corner, just out of sight, is the contemporary speaker system providing the musical atmosphere. Our short walk through the SoY provided a magical moment in a mythical era where we laughed at the progress of turn of the century life, yet marvelled at their more authentic world. We paid the mechanical fortune-teller, Esmeralda, to reveal our futures then wondered about her accuracy. We knew she was not real; yet we wanted her to be. In essence the Streets exhibit was a mixed blessing. It simulated something that never really existed; yet we felt no worse for realizing this. The inauthenticity heightened our enchantment and for a brief moment in time we allowed ourselves to forget the disenchanted world of postmodernity and revel in the luxury of (re) enchantment. As Black [26] reminded us, knowledge should not be characterized only by the "hermetic categories of the Enlightenment, but also by paradox, irony, and contradiction".

A whirl of brilliance: "Oh to be in Fairyland!" This is the way one enchanted visitor wrote about the Carousel Room. Two hundred years ago the Romantic theorists cautioned us that a world surging with rationalism would result in a place stripped of mystery, value, and surprise. But the antithesis between rationalism and romanticism is an illusion and where "romanticism and technology can be seen to grow out of the same ground" [26,27]. Nowhere is this connection more evident at the House on the Rock than in the Carousel room. Near the end of our tour we were transported to an enchanting place basked in red and white lights and filled with calliope music. Touted as the world's largest carousel, this beautiful machine is 80 feet across,
35 feet tall, and weighs 36 tons. A room-sized mirror amplifies the brilliance of the more than 20,000 lights and nearly 200 chandeliers. The carousel's menagerie includes 53 centaurs, three water buffalo, 36 peacocks, three dolphins and not a single horse. "Ahhs, and Wows" dominated the adult exchanges; while children squealed in delight. The experience felt like heaven on earth. But a more sinister experience emerged once we acclimated to the lights and music. Like Berger [28] noted, we no longer simply looked; we began to see unique imagined realities. For example, shrouded in the red light high above our heads was what one of the authors described as floating bodies (mannequins) reminiscent of lost souls swirling in a desperate dance of despair. Like the visitors, these soulless creatures are present but yet barred from participating, never able to join in the heavenly delights of the carousel. But for the other author, they were half-naked dolls with wings reminiscent of mythological figures/goddesses guiding the carousel in a circular dance, embracing the room like lovers. For still another visitor they reflected common stereotypes for women (Madonna, mistress, sex-object). The Carousel also symbolizes the juxtaposition of the rational and the romantic. As a machine the Carousel is a product of the rational, designed to circle flawlessly for hours every day. The gears silently produce a logical outcome that relies on laws of physics. Yet the machine is also a product of Romanticism and part of a society dedicated to spectacle. These two aesthetics merge to create an experience that seems ethereal but absolutely controls and manipulates those who experience it. All interpretations are correct. Like the floating bodies above the carousel, visitors are controlled, manipulated, and enchanted by the wizard behind the curtain, Alex Jordan (now long dead) who (still) conjures up a sense of wonder that lingers long after leaving the grounds.

\section{Working the magic}

If invoking is the act of utilizing specific symbols in an effort to summon particular responses, working magic is the resulting collaborative meanings that emerge from rhetorical efforts. Such meanings, called forth by the patterned, thematic use of symbols, implicate a world that ought to be, a world of possibilities and potentialities. As Starhawk made clear, working magic is a generative practice rooted in the powers of liberation, transformation and directed toward the restrictive beliefs, values, and structures of a disenchanted world. To work magic, then, is to re-examine predominant perceptions and epistemologies and bring forth news ways, or perhaps old ways cast in a new light, of thinking, knowing, and doing. In other words, rhetorical magic is about creating a vision for change. When considered part of Starhawkian rhetoric of (re)enchanted, magic is an intentional invocation, a calculated call for change that presents an alternate, communal consciousness to those who embody sacred space. In this project we found that this happens in two distinct ways: through displacement and the sublime.

Displacement: Displacement played a role in the way we addressed the out of place and the unbelievable that we experienced during and after our visit. Many theorists have tackled the idea of displacement. Freud [29] for example, used the term to investigate imagination and dream processes. Derrida [30] in his discussion of Freud, used displacement to illustrate his ideas about archives and historical repression. Derrida [30] suggested that to archive is to control memory and that, in turn, reinforces dominant social order. Derrida [30] claimed archivingas-displacement is a way to subvert reconstruct history, create an alternative world, to gain immortality. Feminist literary critic, Waugh [31] used displacement to understand the subject/object antithesis in novels. We borrow this term from cultural anthropologists Hastrup 
and Olwig [32] who used it to describe "temporary instances of unrest and disorder". Hastrup and Olwig [32] addressed particular localities as case studies, and focused on forced migration as a result of social upheavals like civil war or natural disasters. Displacement, for them, is a useful framework for understanding de-stabilization of human relationships in postmodern society. For our purposes, displacement is a magical experience that integrates imagined feelings with the $\mathrm{n}$ egotiation of the contradictions we face in everyday life.

In embodied (re) enchantment, identity is critical to the displacement process, and historical origin is unclear. This is especially true for the HOTR because there are no documentations to distinguish the "real" from the "reproductions". Since Jordan was a "collector of collections", he dismissed the need for authenticating artifacts. The HOTR re-enforces, suspends, and transforms belief by nourishing imagination. As we moved through the exhibits we often commented on our own imagined realities. For one it was a journey through a house of terror with spectres and ghosts teasing us at every turn. For the other it was a palace of toys and gadgets with thoughts of "what would it be like to have that in the family room" type of comments. As we strolled the Streets of Yesterday we imagined we were transported back in time. Each shop overflowing with genuine memorabilia and clever reproductions such as whale oil lamps, "antique" toys, and wanted posters of dastardly villains who may be just around the corner "With the Streets, Jordan gave his imagination free rein" [32]. Patrons follow his unknown lead, and allow our imaginations the same latitude. We overheard comments such as, "I never imagined a place like this existed!" And "No one will believe it!". Imagination enchants; and enchantment transforms. But what is striking is, because of displacement, each of us imagined something unique and wonderful. At the House on the Rock we experienced pure simulacra that included reproductions of nostalgic memories. And, what we experienced connected us to the millions of visitors' and their interactions with Jordan and his house since 1960.The House on the Rock maintains its magical quality by changing with the times to include the expectations and mediated memories of each new generation who drop in. Jordan's original intention may have been a weekend retreat on Shelter Rock, but it is now, like Route 66 and Wood [25] a tempting replacement for the original where "the meaning is too real to be limited to reality". Places like the House on the Rock provide us with a chance to embrace contradictions. On one hand it reinforces the status quo. We follow the rules by paying to see the collections, and minding all signs and placards while visiting. We do not touch; we do not go beyond the ropes. We willingly stay on the path. Yet we actively suspend our belief in the rationality of the "real" world when we enter the house. When the guide claims the serpent in the nautical room is "as tall as the Empire State Building" we want to believe it is true (even though we "know" it is not.). The Portland Oaks in the Streets of Yesterday are really cemented but we swear we can smell the bark and hear the leaves rustling. We believe the story Jordan used to tell that the trees only grew at night. We spend our Jordan money for fortune-telling and playing the magical musical machines. The entire experience contributes to our contradictory emotional responses. In reality we were under the spell that was easily broken (there is after all, a pizza joint and modern facilities hidden behind the storefronts). But we do not care. Our beliefs are re-enforced and suspended and this results in transformation. We willingly take part in these rituals of participation, but, at the same time, we may resist them. Like Serrell and Young $[33,34]$ noted museum "experts" who wrote about their own visits to the HOTR, we acknowledged we were changed by our magical experience. The contradiction makes the visit worthwhile. Doane [35] once said,
"We live under continual threat of two equally fearful, but seemingly opposed, destines: unremitting banality and inconceivable terror". At the HOTR we cannot ride or touch the magical carousel. But, just like the ghostly spectres that blink in and out of our peripheral vision, we are both part of the scene and separate from it. Yet we are touched by it. The HOTR is a dimension of excess and distortion, of beauty and freak show, and a place where one can't imagine leaving, a place that magically lures you in, while, at the same time, it is a space that conjures a sense of running for your life. You are part of a contradiction: viewing from a distance, and imagining you are part of the scene. You not only see the images, you are the images and others see you as such. The experience is unsettling because at least two reactions are at work. First is the "ahha moment" that startles you, and the second occurs once you acclimate to the overwhelming sights and sounds and see what is actually flying overhead and then enveloping you. Once you experience space in this way you are in a state of embodied (re) enchantment. The terror and the unrest is now part of you, and you like it. There is no turning back.

The sublime: Perhaps the greatest challenge of engaging the House on the Rock as a form of rhetorical (re) enchantment is its ineffability. Although visitors, and critics, offer descriptions and accounts of their journey through Jordan's architectural dream come true, any attempt to make logical sense of the gallimaufry of collected objects is doomed to failure. Nevertheless, visitors seem drawn to the emotional experiences evoked by the immense, meaning defying hodgepodge. Comments from previous visitors preserved in countless guest books and attraction ephemera include comments such as "I am haunted by this house", and "unsettling". The enormity of the architectural project turned quasi museum, as well as the commitment to continued expansion, summoned conflicting feelings in us as we proceeded through the seemingly never-ending hallways: amazement and disgust, wonder and dread, immensity and triviality, the beautiful and the grotesque. Such emotions, conjured by embodied encounters with various exhibits within the tour, are often associated with the rhetorical sublime.

As Longinus [36] suggested roughly 1,800 years ago, the person subsumed by the sublime feels as if he is "assailed, not by any particular emotion, but by a tumult of different emotions". For Loginus [36], the sublime emerges as rhetorical practice that calls on individuals to transcend commonplace understandings and ponder the possibilities lying beyond conventional human discernment. Lochhead [37] wrote, "as a concept of extremes", the sublime elicits a deep, emotional response to that which is so awe inspiring, beautiful, or grotesque as to be almost unbearable or painful. Sublime rhetoric moves beyond the epistemological frames of "formal convention", ignores "pre-established rules", and "defies existing forms of conceptual understanding". Aligned more with form than function, the sublime resists aesthetic categorization and thwarts attempts to apply logic as sense-making apparatus.

Indeed, the House on the Rock speaks to this "potency of the sublime as transgressor" [38]. Wandering through the space, we were struck by the immensity of the sprawling exhibit. The name implies a domestic living space constructed on a stone foundation and the view from outside the building obfuscates the nature and dimensions of the complex. In fact, once we started walking through the various tours we wondered to ourselves whether the HOTR transcended traditional notions of space and seemed larger on the inside than the outside. The size of the exhibit, coupled with the twisting corridors and never-ending displays, provides a sense of a never-ending journey, or a quest never 
quite finished. After we completed our five-hour tour and reflected on our experience, we discovered each of us had missed particular displays, collections, or even entire rooms, tempting us to re-enter the maze and begin our journey anew. At the same time, we dreaded a return to the labyrinthine corridors and physically cluttered exhibits. We resisted the temptation but could not shake the sense something more was just around an unnoticed corner or hiding in an overlooked alcove. Although we marveled at the commitment needed to envision, construct, and maintain such a sizeable attraction, we questioned the purpose. In addition to the physical vastness of the exhibit and the overwhelming number of collections, we found ourselves marveling at the immensity of the collections themselves. For example, The Streets of Yesterday offers everything from a collection of medical memorabilia, to 100 s of porcelain (authentic Victorian-era?) dolls. The pathways are clouded in dim red-black lights while every storefront is lit in bright a white-yellow hue that draws a visitor's attention to the center of each display. Every nook, cranny, shelf, and window, seems to offer yet another curiosity to entice onlookers. The Carousel Room offers an example of the almost incomprehensible immensity of the collections. A carousel is a familiar attraction for anyone acquainted with county fairs and amusement parks and, to some degree, the carousel at the House on the Rock is an obvious twin. Once one stands in this room for a few moments, however, the differences become almost overwhelming. At first glance the carousel, the only illuminated feature of an otherwise dark room, casts a spell of enchantment and visitors stand transfixed, staring at the whirling spectacle that includes six-foot golden peacocks perched on the top, with a herd of 269 mythological creatures circle below, and tens of thousands of dazzling lights and traditional calliope music working together to cast a hypnotic spell. Additional carousel creatures cover every inch of wall space; the carved angels and seraphim floating overhead add to the massiveness of the collection. The sense of wonder at the sheer audacity and grandeur of it all fades eventually as the visual and auditory onslaught becomes almost too much to bear.

The sprawling collections, anchored in a too-much-is-neverenough ethos, call on visitors to contemplate the possibility of human invention. What started as a project to construct a bucolic getaway morphed into a (re)enchanted space of unique architectural value exhibiting an almost anything is possible aesthetic. On one hand, the HOTR invites visitors to consider the planning, persistence, and care infused in the essence of each individual piece incorporated into every exhibit. The attraction embodies a Midwestern work ethic in the amount of practical maintenance and care required to maintain the actual facility, and in the way the House requires visitors to keep pushing toward the next exhibit, the next collection. Visitors simultaneously witness the rewards associated with hard work as well as embody the Midwestern value as they negotiate meandering paths, cobblestone streets, and lengthy ramps. On the other hand, the ostentatiousness of the attraction, the spectacle of it all, belies the humility frequently associated with the Midwest work ethic and stands as a transcendent, awe-inspiring testament to human imagination. The House on the Rock transforms everyday material artifacts, a recreated city street, a carousel, from the mundane to the magical. An individual's inventive encounter with these redeployed artifacts "takes him out of himself. That which is admirable ever confounds our judgment, and eclipses that which is merely reasonable or agreeable. To believe or not is usually in our own power; but the Sublime, acting with an imperious and irresistible force, sways every reader whether he will or no" [36]. Removed from their everyday context, and displayed so individuals cannot avoid seeing from a new perspective, familiar objects are transformed from household items to pieces of art, from street corner to active nostalgia, from childhood amusement ride to overwhelming visual spectacle. Our point here is that The House on the Rock creates a collision between pragmatic, logical understandings of everyday life and a view of everydayness infused with imagination and magic. A carousel is no longer simply a children's ride but is (re)enchanted as a site of artistic inspiration.

\section{Discussion: Going/Returning}

The nomadic and transitory negotiation of everyday life suggests an individual eventually removes herself from a (re)enchanted space and moves on to encounter and inhabit other spaces and, subsequently, the values associated with those spaces. Thus, a person could move between disenchanted and (re)enchanted space several times a day. In the five hours we were immersed in Alex Jordan's world we felt both part of and removed from reality. This paradox is especially true of the Streets of Yesterday and our differing reactions. Imbued with the whispers of (re)enchanted space, a person returns to the hegemonic discourses of the broader culture and juxtaposes the vision of the world as it ought to be with the world that is. The journey between disenchanted and (re)enchanted space, and the subsequent collision of conflicting value systems, brings the deficits and problematic of a predominant culture into sharp relief. In other words, the encounter with (re) enchantment helps portray a different way of living and illuminates the stories of estrangement that pervade many people's lives. Before an individual is able to resist social control, he must be able to identify the systems of institutionalized disenchantment at work within his own life. Identifying these societal ills, an individual can "make a conscious choice to step away from the mainstream culture and many of its values" [3]. As one leaves the House on the Rock and makes the move back to the day-today encounters that constitute human social life, the magic of intimacy, nostalgia, and the sublime continues to disorient and perplex. This odd architectural attraction encourages viewers to question traditional sense-making and rationality. The (re)enchanted rhetoric of HOTR reminds visitors that relying solely on abstractions of the human experience (e.g., defining voting constituencies via statistical trends), measuring human interconnection by "likes" and "followers", reducing human interactions to behavioral genetics, diminishes the complexity of human being. To be human, suggests Jordan's constructed legacy, is about quantifiable certainties and about uncertainties. The twisting corridors and head scratching collections, none of which seem to fit together in any discernible pattern, are reminiscent of the unorganized messiness of a contemporary, fragmented life. As Starhawk [19] pointed out, individuals living in the tumultuous rapidity of day-today existence experience a great deal of anxiety and frustration as they struggle to control "what is inherently uncontrollable". Whether it's the contradictory displacement inherent in a recreated main street that has no original referent or the disorienting majesty and grotesqueness of the world's largest carousel experiencing the House on the Rock invites visitors to acknowledge the perplexity and ineffability of human experience. The House on the Rock resists traditional notions of order and calls on visitors to embrace "an order that is flexible and open to change, an order that recognizes its own limits and leaves room for wonder and mystery".

The possibility of transformation associated with the recognition of magic, mystery, and wonder in the House on the Rock is a prime illustration of the spatial imagination. Spatial imagination, as a confluence of material artifacts, mediated images, and individual, as well as collective, discernments, presupposes an active participation on the part those who simultaneously interpret and inhabit constructed spaces [39].These imagined spaces, then, emerge as a site of human 
Citation: Pierce T, Sweet D (2014) Magik on the Mounds: The (Re) Enchanted Spaces of the House on the Rock. Arts Social Sci J 5: 062. doi: 10.4172/2151-6200.1000062

Page 8 of 9

accomplishing through which rhetors and audiences articulate understandings, deliberate matters of public consequence, and negotiate the ins and outs of social living. This is particularly evident in the House on the Rock's perplexing mishmash of authenticity and inauthenticity, an intermingling of reality and fantasy that obscures the differentiation between disenchantment and (re) enchantment. The fixity of meaning often associated with material symbols gives way to ephemerality, a move that situates inhabitants in co-created environments as makers, creators, and doers [40]. So while the conflicting authenticity and inauthenticity of the Streets of Yesterday may be exasperating, the placement of early $20^{\text {th }}$ century fortune telling machines on the sidewalk of a $19^{\text {th }}$ century Main Street perplexes us, the lack of concrete meaning leaves the work of sense making to each individual. What is unique in the House on the Rock, however, is people encounter the intersection of fixity and ephemerality in the familiar context of a home, a main street, and a carousel thereby urging them to carry these experiences with disenchantment and (re) enchantment back to their own inhabited spaces. Whether people are in the House of the Rock or in their own home, they "are of the world and of each other and eventually come together, share their understandings, and construct new meaning together [20].Thus, the rhetorical encounters in one space carry over into encounters in another space; shaped by the spaces they encounter individuals also shape the spaces encountered.

As we returned from our academic journey wherein we steeped ourselves in the (re)enchanted rhetoric of the House on the Rock, we found ourselves once again confronted by the cultural obsession with disenchantment. When we shared our research with a psychologist colleague she dismissed our musings and suggested sometimes a cake is just a cake; the House on Rock may be nothing more than a jumble of collections and exhibits constructed for the sole purpose of entertainment. When we heard these comments we could not help but feel some kinship toward E.T.A Hoffman's main character, Maria. Our imaginative rhetorical reading of the eclectic roadside attraction was dismissed, not unlike Maria's account of the Nutcracker, Mouse King, and magical encounters, as some kind of academic fever dream. This exchange exemplifies the rhetorical tension inhabiting the space at House on the Rock. The ongoing clash between disenchantment and (re) enchantment is a struggle and negotiation between competing rhetorical dialectics: authenticity and reproduction, external control of movement and the freedom to get lost, or the search for real historical origin and a nostalgic yearning for what never existed. As we have articulated throughout this piece, embodied (re) enchantment involves the transformation that occurs when we realize we are both the source, and the result, of those contradictions. Acknowledging the embodied (re) enchantment resulting from encounters with the wonder, mystery, and magic of (re)enchanted space calls people to see the world, and act in the world, in new ways.

\section{References}

1. Hoffmann ETA $(1853,2012)$ The nutcracker and the mouse king. [eBook]. Google Books.

2. Zipes JD (2002) Sticks and Stones: The troublesome success of children's literature from Slovenly Peter to Harry Potter. New York Routledge.

3. Starhawk, Valentine $\mathrm{H}(2000)$ The twelve wild swans: A journey to the realm of magic, healing, and action. New York NY: Harper SanFrancisco.

4. Weber M, Gerth HH, Mills CW (1946) Science as vocation. Max Weber: Essays in sociology New York, NY: Oxford University Press. 129-156

5. Gerth HH, Mills CW, Weber (1948) Introduction: The man and his work Max Essays in. New York, NY: Oxford University Press 3-76.

6. Jenkins R (2000) Disenchantment. Enchantment and re-enchantment: Max
Weber at the millennium. Max Weber Studies 1: 11-32.

7. Landy J, Saler M (2009) The re-enchantment of the world: Secular magic in a rational age. Stanford CA: Stanford University Press.

8. Bennett J (2001) The enchantment of modern life: Attachments, crossings, and ethics. Princeton, NJ: Princeton University Press.

9. Leopold A (1949) A Sand County almanac and sketches here and there. New York: Oxford University Press.

10. Foss SK (1986) Ambiguity as persuasion: The Vietnam Veterans Memorial. Communication Quarterly 34: 326-340.

11. Blair C, Jeppeson MS, Pucci E (1991) Public memorializing in post modernity: The Vietnam Veterans Memorial as prototype. Quarterly Journal of Speech 77 263-288

12. Blair C (2001) Reflections on criticism and bodies: Parables from public places Western Journal of Communication, 65: 271-294.

13. Dickinson G (1997) Memories for sale: Nostalgia and the construction of identity in Old Pasadena. Quarterly Journal of Speech 83: 1-27.

14. Dickinson G, Ott B L, Aoki E (2005) Memory and myth at the Buffalo Bill Museum. Western Journal of Communication 69: 85-108.

15. Dickinson G, Ott BL, Aoki E (2006) Spaces of remembering and forgetting: The reverent eye/l at the Plains Indian Museum. Communication \& Critical/Cultural Studies 3: 27-47.

16. George J (2008) Small town essentials: Constructing old world charm in backwater communities. Continuum: Journal of Media \& Cultural Studies 22 827-838.

17. Cameron DF (1972) The museum: A temple or a forum. In G. Anderson (2004) Reinventing the museum: Historical and contemporary perspectives on the paradigm shift, (pp. 61-73). Walnut Creek, CA: AltaMira Press.

18. Foss SK, Griffin CL (1992) A feminist perspective on rhetorical theory: Toward a clarification of boundaries. Western Journal of Communication, 56: 330-349.

19. Starhawk (1989) Truth or dare: Encounters with power, authority, and mystery. New York NY: Harper SanFrancisco.

20. Starhawk (1997) Dreaming the dark: Magic, sex, and politics. Boston MA Beacon Press.

21. Starhawk (2004) The earth path: Grounding your spirit in the rhythms of nature. New York, NY: Harper SanFrancisco.

22. Starhawk (1999) The spiral dance: A rebirth of the ancient religion of the great goddess. New York, NY: Harper SanFrancisco.

23. Covino WA (1994) Magic rhetoric and literacy: An eccentric history of the composing imagination. Albany NY: State University of New York Press.

24. Donaldson SA (2012) The House on the Rock commemorative book. Spring Green, WI: Author.

25. Wood A (2010) Two roads diverge: Route 66, and the mediation of American ruin. Critical Studies in Media Communication 27: 67-83.

26. Black JD (2002) The politics of enchantment: Romanticism, media, and cultura studies. Waterloo, ON CA: Wilfrid Laurier University Press.

27. Ong WJ (1971) Rhetoric, romance, and technology. Studies in the interaction of expression and culture. Ithaca, NY: Cornell University Press.

28. Berger J (1972) Ways of seeing. New York: Penguin.

29. Freud S (2004) The interpretation of dreams. The complete and definitive text Nu Vision Publications.

30. Derrida J (1996) Archive fever. A Freudian impression. Chicago: University of Chicago Press.

31. Waugh P (1989) Feminist fictions: Revisiting the postmodern. NY: Routledge.

32. Hastrup K, Olwig FK (1997) Introduction. In sitting culture: The shifting anthropological objects. New York: Routledge 1-14.

33. Serrell B (2011) The House on the Rock. Exhibitionist 24-27.

34. Young PA (2001) Forum: Nightmare down memory lane Archaeology. January/ February, 80.

35. Doane MA (1990) Information, crisis, catastrophe. Logics of television. Essays 
Citation: Pierce T, Sweet D (2014) Magik on the Mounds: The (Re) Enchanted Spaces of the House on the Rock. Arts Social Sci J 5: 062. doi: 10.4172/2151-6200.1000062

Page 9 of 9

in cultural criticism. Bloomington: Indiana University Press 222-239.

36. Longinus (1980) On the sublime. London: McMillan and Co.

37. Lochhead $\mathrm{J}$ (2008) The sublime, the ineffable, and other dangerous aesthetics. Women and Music: A Journal of Gender and Culture, 12: 63-74.
38. Nesbitt K (1995). The sublime and modern architecture: unmasking (an aesthetic of) abstraction. New Literary History, 26: 95-110.

39. Dickinson G (2006) The Pleasantville effect: Nostalgia and the visual framing of (white) suburbia. Western Journal of Communication, 70: 212-233.

40. De Certeau M (1984) The practice of everyday life. Berkeley and Los Angeles: University of California Press. 